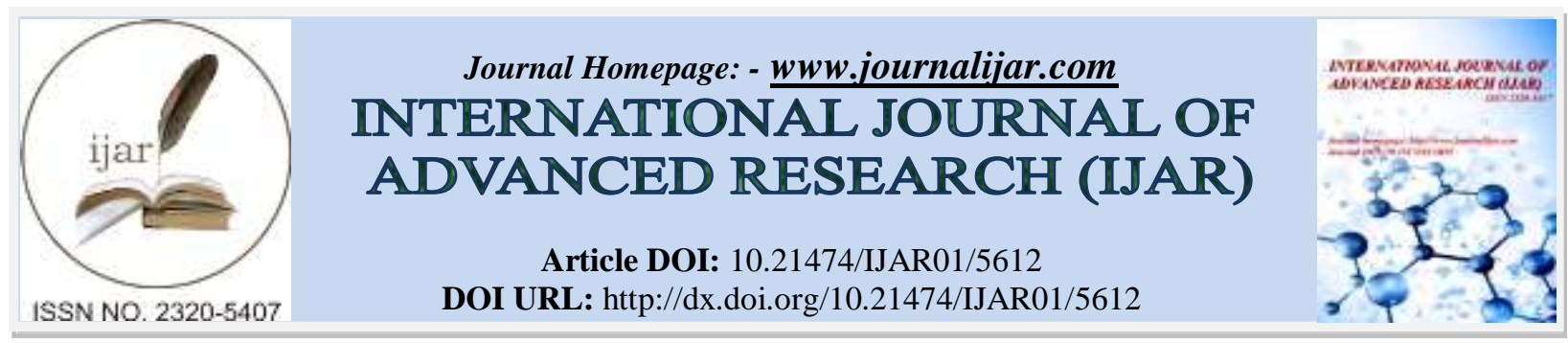

RESEARCH ARTICLE

\title{
ESTIMATION OF EXTRACELLULAR LIGNINOLYTIC ENZYMES FROM WILD AURICULERIA POLYTRICHA, HELVELLA SP. AND MORCHELLA SP.
}

\author{
Neha Thakur, Astha Tripathi*, Sukrit Sagar, Pardeep Kumar, Nagina Devi, Shaveta, Isha Sharma, Monika \\ and Jyoti Sharma. \\ Applied Sciences and Biotechnology, Shoolini University.
}

\section{Manuscript Info}

Manuscript History

Received: 13 August 2017

Final Accepted: 15 September 2017

Published: October 2017

Key words:-

White-rot fungi, Ligninolytic enzymes,

Nutrient rich medium, Nutrient poor medium.

\begin{abstract}
Three mushroom samples have been selected for extracellular ligninolytic enzyme activities i.e commercially cultivated Auricularia polytricha, wild Helvella sp. and wild Morchella sp. To investigate the extracellular ligninolytic enzymes, cultures were incubated over a period of 20 days in nutrient rich medium (NRM) and nutrient poor medium (NPM) under static conditions. Samples showed green and brown coloration in solid medium plates; it indicates the presence of laccase and Manganese peroxidase (MnP). Production of extracellular ligninolytic enzymes were observed in all three species in different pattern. The results of the present study allow us to conclude that wild Morchella sp. and Helvella sp. are good for production of ligninolytic enzymes in comparison to commercially cultivated Auricularia polytricha.
\end{abstract}

Copy Right, IJAR, 2017,. All rights reserved.

\section{Introduction:-}

Fungi have a worldwide distribution and grow in a wide range of habitats including extreme environments such as desert area or areas with salt concentrations or ionizing radiation as well as in deep sea sediments. In addition, they have many medicinal uses and are good agents of bioremediation [1,19]. Mushrooms are highly nutritious containing protein (19-35\%), low fat content (1.3-2\%), relatively large amounts of carbohydrate (51-88\%) and fiber (4-20\%) in dry mushroom fruit bodies [2]. In the physiological point of view, mushrooms are broadly divided into wood rot, mycorrhizal and litter decomposing fungi. The most important and potent wood-destroying organisms are white rot and brown rot fungi. White rot fungi that play a important role in decomposition of dead trees, especially in degradation of lignin. The white rot fungi belonging to the basidiomycetes that produce various isoforms of extracellular ligninolytic enzymes. The main extracellular enzymes participating in lignin degradation are hemecontaining lignin peroxidase (LiP; EC 1.11.1.14), MnP (EC 1.11.1.13) and Cu-containing laccase (EC 1.10.3.2). In addition, enzyme involved in hydrogen peroxide production such as aryl alcohol oxidase (AAO, EC 1.1.3.7) is considered to belong to the ligninolytic system [10].

We have selected three mushrooms strains, Auricularia polytricha, Helvella sp. and Morchella sp. for their extracellular enzymatic studies. The interest of Auricularia polytricha could be easily identified by pilose upper surface which is strongly capitates with dark brown smooth hymenium [13]. Morchella species is one of the most readily recognized of all the edible mushrooms. On the other hand Helvella species they grow in grass as well as humid hardwoods, such as beech, and in hedges and on the talus of meadows. These all are wood decaying WRF produce ligninolytic enzymes. 


\section{Materials and Methods:-}

Fresh fruiting bodies of Morchella and Helvella were collected from forest of Silly forest (1500 M), Himachal Pradesh during rainy season. The fruiting bodies were aseptically collected with the help of knife and carried to laboratory in sterile poly-bags. Mycelial culture of Auricularia polytricha was procured from Directorate of Mushroom Research, Solan (H.P.).

\section{Chemicals Used:-}

Analytical grade 2.2'-azino-bis (3-ethyl benzothiazoline-6-sulphonic acid) (ABTS, MW 548.7 gmol ${ }^{-1}$ ) and Veratryl alcohol (VA, MW $168.19 \mathrm{gmol}^{-1}$ ) was purchased from Himedia. All other chemicals used were of analytical grade.

\section{Screening of ligninolytic enzymes through spot test:- \\ Laccase Spot test:-}

Laccase spot test was done for the screening of extracellular ligninolytic enzyme. Test was performed in $90 \mathrm{~mm}$ diameter Petri-dishes with $20 \mathrm{ml}$ of the modified Kirk medium containing $10 \mathrm{~g}$ of glucose, $2 \mathrm{~g}$ of $\mathrm{KH}_{2} \mathrm{PO}_{4}, 0.5 \mathrm{~g}$ of $\mathrm{MgSO}_{4} .7 \mathrm{H}_{2} \mathrm{O}, 0.1 \mathrm{~g}$ of $\mathrm{CaCl}_{2}, 2.2 \mathrm{~g}$ of 2,2-dimethysuccinate, $0.5 \mathrm{~g}$ of ammonium tatrate, $0.2 \mathrm{~g}$ of yeast extract, $0.2 \mathrm{~g}$ of ABTS, 20g of agar, per liter of medium. The $\mathrm{pH}$ was adjusted to 5.0 before autoclaving at $15 \mathrm{psi}$ and $120^{\circ} \mathrm{C}$ for 20 min. The plates were incubated at $25^{\circ} \mathrm{C}$ for three weeks. The extracellular enzyme ABTS oxidizing activity was measured by the green colour intensity of medium [21].

\section{MnP Spot Test:-}

Fungus culture (previously cultured in $2 \%$ MEA agar for 8 days) were inoculated in the kirk medium containing $10 \mathrm{~g}$ of glucose, $2 \mathrm{~g}$ of $\mathrm{KH}_{2} \mathrm{PO} 4,0.5 \mathrm{~g}$ of $\mathrm{MgSO}_{4} .7 \mathrm{H}_{2} \mathrm{O}, 0.1 \mathrm{~g}$ of $\mathrm{CaCl}_{2}, 2.2 \mathrm{~g}$ of 2,2-dimethylsuccinate, $0.5 \mathrm{~g}$ of ammonium tartrate, $20 \mathrm{~g}$ of agar-agar per liter of medium. For the production of MnP medium was supplemented with $0.04 \mathrm{~g}$ of $\mathrm{MnCl}_{2} \cdot 4 \mathrm{H}_{2} \mathrm{O}$ per liter of the medium. The $\mathrm{pH}$ was adjusted to 5.0 before autoclaving at 15 psi for $20 \mathrm{~min}$ at $120^{\circ} \mathrm{C}$ [22]. Fungal growth was estimated in terms of diameter of fungal colony. Extracellular enzymatic activity was measured by the colour intensity of the medium. Plates were observed once a day for three consecutive weeks.

\section{Extracellular Ligninolytic Enzyme assay:-}

The production of extracellular enzymes were carried out in the NRM containing $2 \mathrm{~g}$ of ammonium tartrate, $10 \mathrm{~g}$ of glucose, $1 \mathrm{~g}$ of $\mathrm{KH}_{2} \mathrm{PO}_{4}, 1 \mathrm{~g}$ of yeast extract, $0.5 \mathrm{~g}$ of $\mathrm{MgSO}_{4} \cdot 7 \mathrm{H}_{2} \mathrm{O}, 5 \mathrm{~g}$ of $\mathrm{KCl}, 1 \mathrm{ml}$ of solution containing trace elements per liter of medium and the NPM containing $10 \mathrm{~g}$ of glucose, $2 \mathrm{~g}$ of $\mathrm{KH}_{2} \mathrm{PO}_{4}, 0.2 \mathrm{~g}$ of yeast extract, $0.1 \mathrm{~g}$ of peptone, $1 \mathrm{ml}$ of solution containing trace elements per liter of medium. Solution of trace elements containing $10 \mathrm{mg}$ of $\mathrm{Na}_{2} \mathrm{~B}_{4} \mathrm{O}_{7} .10 \mathrm{H}_{2} \mathrm{O}, 7 \mathrm{mg}$ of $\mathrm{ZnSO}_{4} .7 \mathrm{H}_{2} \mathrm{O}, 5 \mathrm{mg}$ of $\mathrm{FeSO}_{4} .7 \mathrm{H}_{2} \mathrm{O}, 1 \mathrm{mg}$ of $\mathrm{CuSO}_{4} .5 \mathrm{H}_{2} \mathrm{O}, 1 \mathrm{mg}$ of $\left(\mathrm{NH}_{4}\right)_{6} \mathrm{MO}_{7} \mathrm{O}_{24} .4 \mathrm{H}_{2} \mathrm{O}$, $1 \mathrm{mg}$ of $\mathrm{MnSO}_{4}$ dissolved in $100 \mathrm{ml}$ of $\mathrm{H}_{2} \mathrm{O}$ [8]. The $\mathrm{pH}$ was adjusted to seven before autoclaving at $15 \mathrm{psi}$ and $120^{\circ} \mathrm{C}$ for $20 \mathrm{~min}, 150 \mathrm{ml}$ flasks containing $50 \mathrm{ml}$ liquid medium were inoculated with 5-8 days old five mycelium bits $(5 \mathrm{~mm}$ in diameter). Three replicates of flaks of both medium were incubated in static condition in BOD incubator and shaking condition in a rotator shaker at $150 \mathrm{rev} / \mathrm{min}$ at $30^{\circ} \mathrm{C}$.

The cultures were harvested at the $5^{\text {th }}, 10^{\text {th }}, 15^{\text {th }}$ and $20^{\text {th }}$ day of incubation. Each sample was centrifuged (10,000x $g$ for $10 \mathrm{~min}$ ) at $4^{\circ} \mathrm{C}$. The supernatant of liquid culture was used for enzyme assay. The enzymatic reactions were carried out in triplicate and determined using a double beam systronics UV/VIS spectrophotometer. All the enzyme activities were measured at room temperature $\left(20 \pm 2^{\circ} \mathrm{C}\right)$. The enzymatic activity was expressed as international units $(\mathrm{U})$ defined as the amount of enzyme required to produce $1 \mu \mathrm{mol}$ product $\mathrm{min}^{-1}$ and expressed as $\mathrm{Ul}^{-1}$.

Protein concentration was determined following Bradford method [3]. Protein content in the sample was determined from standard curve and the amount of protein $1 \mu \mathrm{gml}^{-1}$ was calculated. Laccase activity was measured following the oxidation of ABTS $\left(\varepsilon 420,36,000 \mathrm{M}^{-1} \mathrm{~cm}-1\right)$. The assay mixture contained $100 \mathrm{mM}$ sodium acetate buffer pH 5 and $5 \mathrm{mM}$ ABTS [12]. LiP activity was measured by the oxidation of $2 \mathrm{mM}$ VA to veratraldehyde $\left(\varepsilon 310,9,300 \mathrm{M}^{-1} \mathrm{c}^{-1}\right)$ in $100 \mathrm{mM}$ sodium tartrate buffer $(\mathrm{pH} 3)$ in the presence of $0.4 \mathrm{mM} \mathrm{H}_{2} \mathrm{O}_{2}$ (30\%) [4]. MnP activity was determined by the production of a $\mathrm{Mn}^{+3}$ tartrate complex $\left(\varepsilon 238,6,500 \mathrm{M}^{-1} \mathrm{~cm}^{-1}\right)$ from $0.1 \mathrm{mM} \mathrm{MnSO} \mathrm{M}_{4}$ in $100 \mathrm{mM}$ sodium tartrate buffer $\mathrm{pH} 4.5$ with $0.1 \mathrm{Mm} \mathrm{H}_{2} \mathrm{O}_{2}(30 \%)$ [6].

\section{Statistical Analysis:-}

All the experimental analysis was carried out in triplicates. The results are expressed as mean values and standard deviation (SD). The results were analyzed using one-way analysis of variance (ANOVA) followed by Tukey's HSD Test using SAV v.9.1.3 program. Differences at $\mathrm{P}>0.05$ were considered to be significant. 


\section{Results and Discussion:- \\ Identification:-}

The samples were identified as Helvella sp. and Morchella sp. on the basis of their micro and macroscopic features (Fig.1). In Himachal Pradesh there is a huge variation in climatic conditions due to the variations in altitude (450$6500 \mathrm{~m})$. The climatic condition varies from hot and sub-humid tropical $(450-900 \mathrm{~m})$. Mushrooms have extraordinary capacity to manage climatic conditions.
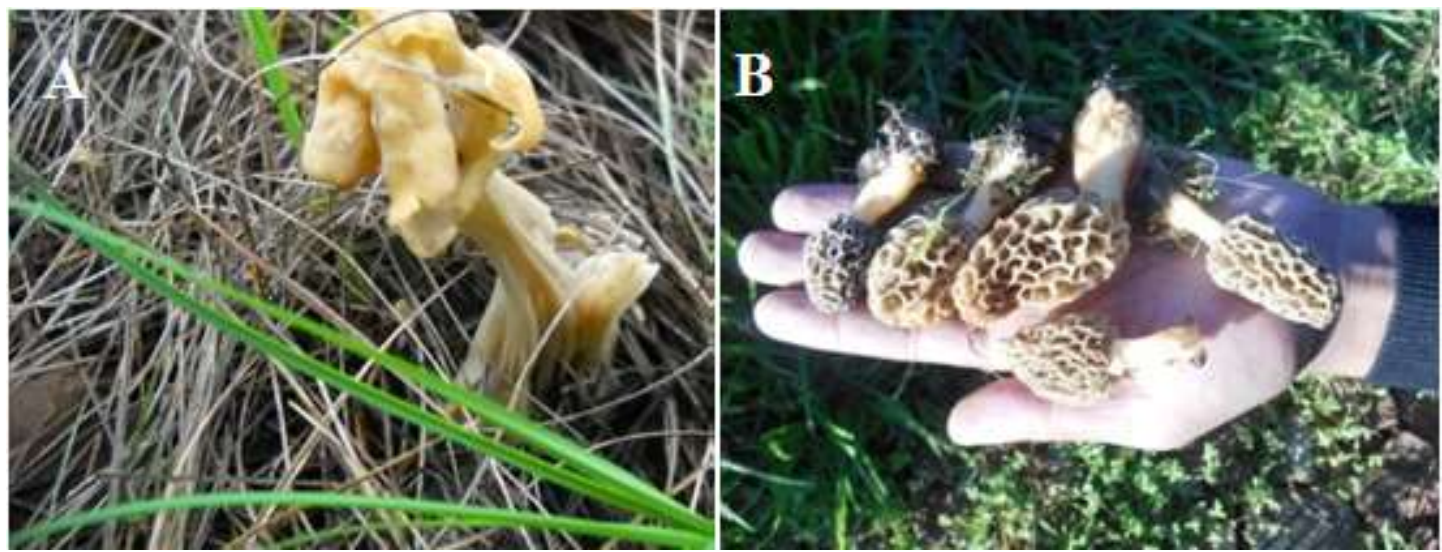

Fig.1:- Natural view of (A) Helvella sp., (B) Morchella sp.

\section{Spot Test of Extracellular Enzymes:-}

With the agar plate screening, selected strains of wood colonizing WRF were tested for spot test. In comparison to the growth on MEA, strains grew noticeably slower on the selected agar media. In particular ABTS had inhibitory effects on fungal growth.

\section{Laccase Spot Test:-}

The extracellular ABTS-oxidizing activity of the both fungal strains into the modified Kirk medium is showed in Fig.2. Morchella sp. showed high ABTS-oxidizing activity in comparison to Auricularia polytricha and Helvella sp. The absence of extracellular ABTS-oxidizing activity does not necessarily imply the lack of capacity to produce these oxidative enzymes but could reflect a possible inhibition of their expression; the oxidative enzyme system is not homogeneous; its production and properties depend on the conditions and culture media. Fungal strains oxidized ABTS to the dark green ABTS cation radicals (ABTS) indicating the production of extracellular oxidoreductases [10]. It gave positive reaction immediately after inoculation, formed dark green zone around the mycelial bit and Auricularia polytricha and Helvella sp. showed green colour after 5 days of inoculation. The green colour preceded the fungal mycelium clearly demonstrating that extracellular mechanisms were responsible for the oxidation [10].

\section{MnP Spot Test:-}

All the three selected species Morchella sp., Auricularia polytricha and Helvella sp. showed positive reaction of extracellular $\mathrm{MnP}$ and formed brownish colour in medium plate (Fig. 2). Helvella sp. and Morchella sp. showed dark brown coloration in comparison to Auricularia polytricha however mycelial growth was noticeably slow in Morchella sp with $\mathrm{MnCl}_{2}$. MnP plates were evaluated after 3 weeks of incubation for the formation of brownish flecks of manganese oxide $\left(\mathrm{MnO}_{2}\right)$ caused by the action of $\mathrm{MnP}$. MnP was thought to play a crucial role during the primary attack on lignin, because it generates highly reactive $\mathrm{Mn}^{3+}$ which acts as a low molecular mass redox mediator and forms water soluble lignin fragments. Moreover, there are indications that $\mathrm{MnP}$ is even capable of mineralizing lignin up to carbon dioxide [10]. It was assumed that $\mathrm{MnP}$ plays an important role in mineralization of lignin. 


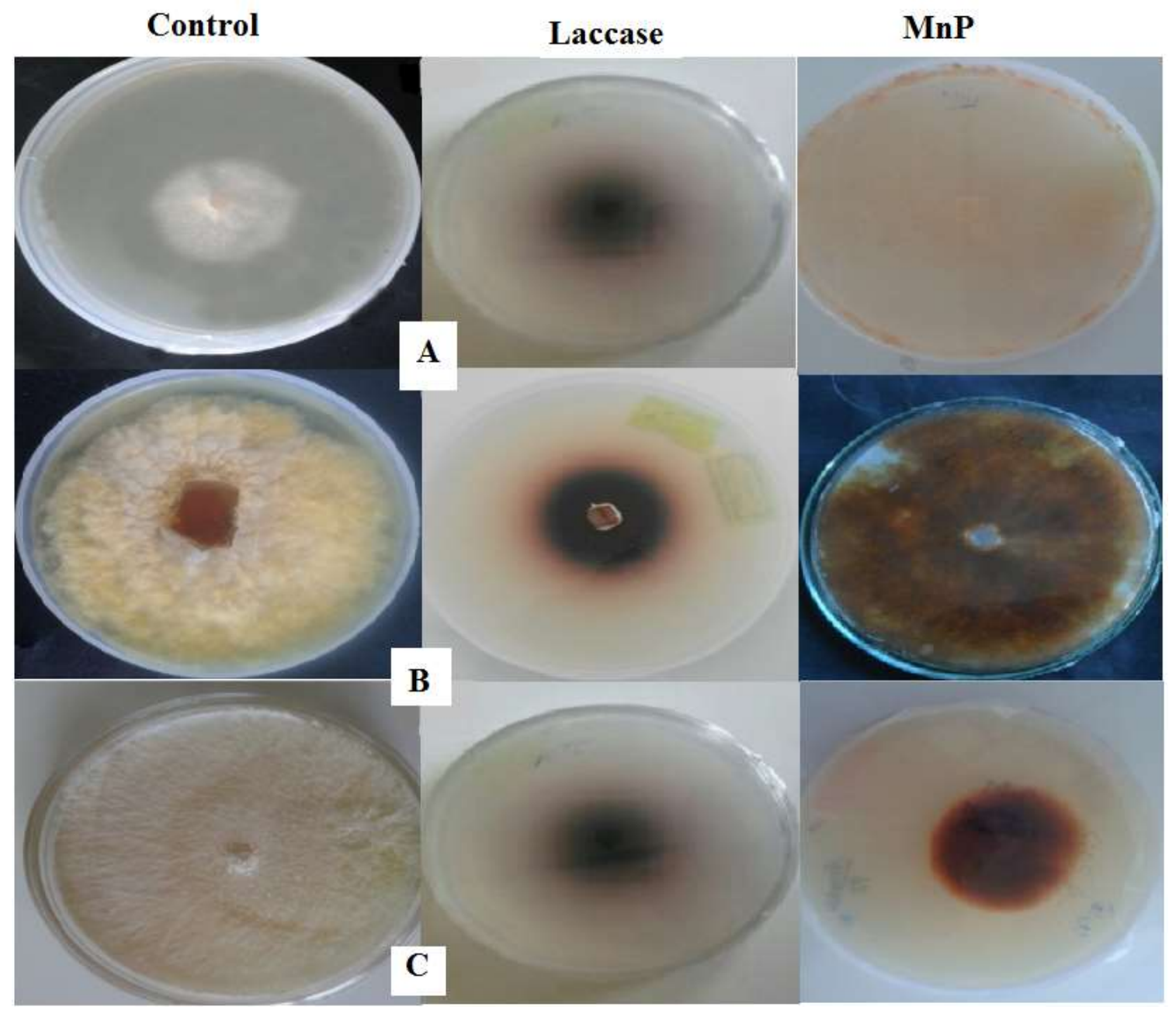

Fig.2:- Extracellular Laccase and MnP activity on agar plate; A- Auricularia polytricha, B- Halvella sp., CMorchella sp.

\section{Extracellular Quantitative Protein Determination:-}

The Bradford assay is a protein determination method that involves the binding of Coomassie brilliant blue G-250 dye to proteins [3]. When the dye binds to protein, it is converted to a stable un-protonated blue form [23]. This is anionic form of dye. In Auricularia polytricha maximum protein concentration was observed on $15^{\text {th }}$ day in NRM and minimum concentration was observed on $5^{\text {th }}$ day NPM $(3.57 \mu \mathrm{g} / \mathrm{ml})$. In Halvella sp. maximum protein concentration was observed on $15^{\text {th }}$ day in NPM $(16.0 \mu \mathrm{g} / \mathrm{ml})$ and minimum concentration was observed on $20^{\text {th }}$ day in NPM $(2.89 \mu \mathrm{g} / \mathrm{ml})$. In Morchella sp. maximum protein concentration was measured on $15^{\text {th }}$ day in NPM (14.53 $\mu \mathrm{g} / \mathrm{ml})$ and minimum activity was observed on $10^{\text {th }}$ day in NPM $(2.3 \mu \mathrm{g} / \mathrm{ml})$. In all three selected varieties protein concentration was higher on $15^{\text {th }}$ day in both medium.

\section{Extracellular Ligninolytic enzyme assay:-}

Laccase: Laccase was first detected in the Japanese lac tree Toxicodendron verniciflua. Later, it was found in certain other plants and fungi, but is also found in molds, black yeasts and some bacteria [17]. Laccase has been identified as one of the enzyme that plays a major role in lignin degradation. Laccase only attacks phenolic subunits of lignin, but its substrate range can be extended to non-phenolic subunits by the inclusion of a mediator [17]. In Auricularia polytricha maximum laccase activity was observed on $10^{\text {th }}$ day in NRM $\left(63.54 \mathrm{UL}^{-1}\right)$ and minimum was observed on $20^{\text {th }}$ day in NRM $\left(47.21 \mathrm{UL}^{-1}\right)$. In Helvella sp. maximum laccase activity was observed on $10^{\text {th }}$ day in NPM $\left(73.17 \mathrm{UL}^{-1}\right)$ and minimum was observed on $20^{\text {th }}$ day in NPM $\left(43.86 \mathrm{UL}^{-1}\right)$ respectively. In Morchella $\mathrm{sp}$. maximum laccase activity was observed on $10^{\text {th }}$ day in NRM (67.3UL-1) and minimum was observed in NRM on $20^{\text {th }}$ day $\left(48.63 \mathrm{UL}^{-1}\right)$. It was witnessed that supplementation and incubation conditions also affected the enzymatic 
activity. A few WRF gave good laccase activity under high nitrogen condition and medium supplemented with Cu but in the absence of $\mathrm{Cu}$ activity was not found and under low nitrogen like Volvariella volvacea, Piloderma byssinum. [5]

\section{AAO:-}

The lignin degradation system of WRF is mainly composed of laccase, LiP and MnP. It is considered that, these lignin degrading enzymes do not functions but mutually interact with each other as well as with other oxidases, such as AAO. AAO activity was described for the first time in the fungus Polystictus versicolor (a synonym of Trametes versicolor) in 1960 [9]. Since then, AAO has been detected and characterized in other white-rot basidiomycetes including Pleurotus species, Bjerkandera adusta and some ascomycetous fungi [14]. AAO is the main oxidase enzyme is all selected varities. In Auricularia polytricha maximum AAO activity was observed on $10^{\text {th }}$ day in

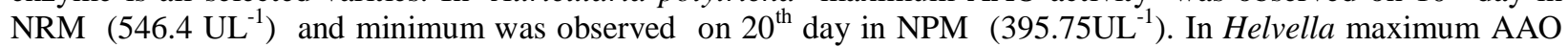
activity was observed on $10^{\text {th }}$ day in NPM $\left(509 \mathrm{UL}^{-1}\right)$; and minimum was observed on $20^{\text {th }}$ day in $\mathrm{NRM}^{\left(369.2 \mathrm{UL}^{-}\right.}$ $\left.{ }^{1}\right)$. In Morchella sp. maximum AAO activity was observed on $5^{\text {th }}$ day in NRM $\left(550.42 \mathrm{UL}^{-1}\right)$ and minimum activity was observed on $10^{\text {th }}$ day in NPM $\left(468.5 \mathrm{UL}^{-1}\right)$.

LiP:-

One of the best known ligninolytic enzymes is LiP, which was discovered a little earlier than MnP [15]. LiP is a glycoprotein that contains one mole of iron protoporphyrin IX as a prosthetic group. LiP catalyzes the oxidation of non-phenolic aromatic compounds like veratryl alcohol. In Auricularia polytricha maximum LiP activity was observed on $15^{\text {th }}$ day in NRM $\left(44.56 \mathrm{UL}^{-1}\right)$ and minimum activity was observed on $5^{\text {th }}$ day in $\mathrm{NRM}\left(1.0 \mathrm{UL}^{-1}\right)$. In Helvella sp. maximum LiP activity was observed on 15 th day in NPM (51.38 $\left.\mathrm{UL}^{-1}\right)$ and minimum activity was observed on $5^{\text {th }}$ day under static conditions $\left(1.0 \mathrm{UL}^{-1}\right)$. In Morchella sp. maximum LiP activity was observed on $15^{\text {th }}$ day in NPM $\left(55.29 \mathrm{~L}^{-1}\right)$ and minimum activity was observed on NPM in $20^{\text {th }}$ day $\left(4.29 \mathrm{UL}^{-1}\right)$.

\section{MnP:-}

$\mathrm{MnP}$ is a second group of extracellular enzymes secreted by WRF. MnP operate by oxidizing $\mathrm{Mn}^{2+}$ to chelated $\mathrm{Mn}^{3+}$, which acts as a diffusible oxidant at locations remote from the enzyme active site. MnP is widely distributed in WRF, including P. chrysosporium, P. radiata, Nematoloma frowardi, P. eryngii and B. adusta [14] and this peroxidase described for the first time in B. adusta [14]. In Auricularia polytricha maximum MnP activity was observed on $15^{\text {th }}$ day in NPM $\left(46.4 \mathrm{UL}^{-1}\right)$ and minimum activity was observed on $5^{\text {th }}$ day in NPM $\left(1.04 \mathrm{UL}^{-1}\right)$. In Helvella sp. maximum MnP activity was observed on $15^{\text {th }}$ day in NPM and minimum was observed on $5^{\text {th }}$ day in NRM $\left(2.33 \mathrm{UL}^{-1}\right)$. In Morchella sp. maximum MnP production was observed on $15^{\text {th }}$ day in $\left.\mathrm{NRM}^{(57.32 \mathrm{UL}}{ }^{-1}\right)$ and minimum activity was observed on $20^{\text {th }}$ day in $\mathrm{NRM}\left(9.73 \mathrm{UL}^{-1}\right)$.

Mushrooms are recognized as important food items since ancient times. Their usage is being increased day by day for their significant role in human health, nutrition and disease. Fungi are ideal food because they have a fairly high content of protein (typically $20-30 \%$ dry matter as crude protein) which contains all of the essential amino acids [17]. For carrying out our study, we first selected three species two wild that is Morchella sp. and Helvella sp. and one commercially cultivated Auricularia polytricha. The extracellular laccase, AAO, LiP and MnP are thought to be involved in lignin degradation by WRF, which produce different combination of these extracellular enzymes. Proteins, Laccase and MnP production was maximum in Helvella sp. AAO (Aryl Alcohol Oxidase) production was maximum in Auricularia polytricha however Morchella sp. showed high LiP activity. In WRF laccase besides functioning as lignin degrading enzyme, it was also important in pigment production, polyphenol detoxification, fruiting body formation, sporulation and antimicrobial agent [7]. In general Laccase and MnP are more widely distributed among WRF than LiP [20]. Production of enzymes was good in Morchella and Helvella sp. in comparison to Auricularia polytricha (Table-1).

Table 1:- Extracellular protein $\left(\mu \mathrm{gml}^{-1}\right)$ and ligninolytic enzymes $\left(\mathrm{Ul}^{-1}\right)$

\begin{tabular}{|l|l|l|l|l|l|l|l|}
\hline \multirow{2}{*}{ S.No } & \multirow{2}{*}{$\begin{array}{l}\text { Day } \\
\text { interval }\end{array}$} & Auricularia polytricha & Helvella sp. & \multicolumn{2}{l|}{ Morchella sp. } \\
\cline { 2 - 8 } & NRM & NPM & NRM & NPM & NRM & NPM \\
\hline \multirow{3}{*}{ Protein } & 5 & $3.57 \pm 0.2^{\mathrm{c}}$ & $4.46 \pm 0.11^{\mathrm{dc}}$ & $1.8 \pm 0.48^{\mathrm{d}}$ & $6.92 \pm 1.25^{\mathrm{a}}$ & $2.30 \pm 1^{\mathrm{cd}}$ & $5.42 \pm 0.2^{\mathrm{b}}$ \\
\cline { 2 - 8 } & 10 & $7.13 \pm 12^{\mathrm{d}}$ & $8.41 \pm 0.31^{\mathrm{cd}}$ & $6.2 \pm 0.5^{\mathrm{d}}$ & $11.2 \pm 0.5^{\mathrm{b}}$ & $13.1 \pm 0.3^{\mathrm{a}}$ & $2.3 \pm 0.4^{\mathrm{c}}$ \\
\cline { 2 - 8 } & 15 & $15.43 \pm 0.43^{\mathrm{a}}$ & $12.15 \pm 0.1^{\mathrm{b}}$ & $10.43 \pm 0.22^{\mathrm{b}}$ & $16 \pm 0.5^{\mathrm{a}}$ & $11.36 \pm 1^{\mathrm{b}}$ & $14.53 \pm 1.6^{\mathrm{a}}$ \\
\cline { 2 - 8 } & 20 & $8.21 \pm 0.67^{\mathrm{a}}$ & $6.26 \pm 0.63^{\mathrm{bc}}$ & $6.73 \pm 0.26^{\mathrm{b}}$ & $2.89 \pm 0.61^{\mathrm{d}}$ & $5.1 \pm 1^{\mathrm{c}}$ & $3.95 \pm 0.77^{\mathrm{cd}}$ \\
\hline Laccase & 5 & $58.1 \pm 0.67^{\mathrm{c}}$ & $52.6 \pm 0.49^{\mathrm{d}}$ & $64.53 \pm 0.73^{\mathrm{b}}$ & $69.72 \pm 0.51^{\mathrm{a}}$ & $55.6 \pm 0.7^{\text {cd }}$ & $64.35 \pm 0.3^{\mathrm{b}}$ \\
\hline
\end{tabular}




\begin{tabular}{|l|l|l|l|l|l|l|l|}
\hline \multirow{5}{*}{} & 10 & $63.54 \pm 0.5^{\mathrm{c}}$ & $62.2 \pm 0.5^{\mathrm{c}}$ & $66.49 \pm 1.5^{\mathrm{bc}}$ & $73.17 \pm 1.5^{\mathrm{a}}$ & $67.3 \pm 0.2^{\mathrm{b}}$ & $65.6 \pm 0.38^{\mathrm{bc}}$ \\
\cline { 2 - 8 } & 15 & $52.9 \pm 0.28^{\mathrm{b}}$ & $50.7 \pm 0.63^{\mathrm{b}}$ & $53.48 \pm 1.9^{\mathrm{b}}$ & $47.57 \pm 0.41^{\mathrm{c}}$ & $59.8 \pm 0.5^{\mathrm{a}}$ & $61.58 \pm 0.3^{\mathrm{a}}$ \\
\cline { 2 - 8 } & 20 & $47.2 \pm 0.36^{\mathrm{b}}$ & $36.21 \pm 0.32^{\mathrm{d}}$ & $51.63 \pm .57^{\mathrm{ab}}$ & $43.86 \pm 0.56^{\mathrm{c}}$ & $48.63 \pm 0.4^{\mathrm{b}}$ & $53.5 \pm 0.5^{\mathrm{a}}$ \\
\hline \multirow{5}{*}{ AAO } & 5 & $557.1 \pm 1.45^{\mathrm{a}}$ & $528.7 \pm 1.83^{\mathrm{a}}$ & $483.63 \pm 1.05^{\mathrm{b}}$ & $42.05 \pm 1.06^{\mathrm{c}}$ & $550.42 \pm 0.52^{\mathrm{a}}$ & $449.52 \pm 0.5^{\mathrm{bc}}$ \\
\cline { 2 - 8 } & 10 & $546.4 \pm 1.8^{\mathrm{a}}$ & $539.4 \pm 1.36^{\mathrm{a}}$ & $474.71 \pm 1.3^{\mathrm{c}}$ & $509 \pm 1.5^{\mathrm{b}}$ & $532.1 \pm 0.3^{\mathrm{a}}$ & $468.5 \pm 0.8^{\mathrm{c}}$ \\
\cline { 2 - 8 } & 15 & $494.2 \pm 1.4^{\mathrm{a}}$ & $472.15 \pm 138^{\mathrm{c}}$ & $482.4 \pm 1.07^{\mathrm{b}}$ & $468.6 \pm 11^{\mathrm{cd}}$ & $486.6 \pm 0.2^{\mathrm{ab}}$ & $464.4 \pm .4^{\mathrm{d}}$ \\
\cline { 2 - 8 } & 20 & $457 \pm 1.67^{\mathrm{a}}$ & $395.7 \pm 1.96^{\mathrm{b}}$ & $369.2 \pm 1.01^{\mathrm{c}}$ & $376.2 \pm 1.1^{\mathrm{bc}}$ & $452.7 \pm 0.49^{\mathrm{a}}$ & $462.3 \pm 0.6^{\mathrm{a}}$ \\
\hline \multirow{4}{*}{ LiP } & 5 & $1.1 \pm 1.02^{\mathrm{a}}$ & $1.0 \pm 0.1^{\mathrm{b}}$ & $1.0 \pm 0.1^{\mathrm{b}}$ & $1.31 \pm 0.2^{\mathrm{a}}$ & ND & ND \\
\cline { 2 - 8 } & 10 & $27.72 \pm 3.9^{\mathrm{bc}}$ & $26.04 \pm 46^{\mathrm{c}}$ & $35.52 \pm 1.7^{\mathrm{a}}$ & $24.4 \pm 1.36^{\mathrm{c}}$ & $25.37 \pm 1.4^{\mathrm{c}}$ & $29.72 \pm 3.6^{\mathrm{b}}$ \\
\cline { 2 - 8 } & 15 & $44.56 \pm 1.8^{\mathrm{c}}$ & $40.32 \pm 1.4^{\mathrm{c}}$ & $49.61 \pm 1.3^{\mathrm{b}}$ & $51.38 \pm 2.5^{\mathrm{ab}}$ & $47.26 \pm 1.3^{\mathrm{bc}}$ & $55.29 \pm 3.2^{\mathrm{a}}$ \\
\cline { 2 - 8 } & 20 & $4.56 \pm 2.7^{\mathrm{b}}$ & $6.78 \pm 1.9^{\mathrm{a}}$ & $7.39 \pm 1.03^{\mathrm{a}}$ & $8.33 \pm 0.4^{\mathrm{a}}$ & $7.39 \pm 5.2^{\mathrm{a}}$ & $4.29 \pm 5.4^{\mathrm{b}}$ \\
\hline \multirow{4}{*}{ MnP } & 5 & $1.04 \pm 0.3^{\mathrm{b}}$ & $2.11 \pm 0.6^{\mathrm{b}}$ & $2.33 \pm 0.28^{\mathrm{ab}}$ & $4.8 \pm 0.24^{\mathrm{a}}$ & $\mathrm{ND}$ & ND \\
\cline { 2 - 8 } & 10 & $20.36 \pm 1.8^{\mathrm{d}}$ & $28.53 \pm 1.9^{\mathrm{c}}$ & $35.27 \pm 1.7^{\mathrm{b}}$ & $34.17 \pm 1.6^{\mathrm{b}}$ & $38.28 \pm 3.8^{\mathrm{a}}$ & $37.12 \pm 1.2^{\mathrm{ab}}$ \\
\cline { 2 - 8 } & 15 & $41.53 \pm 1.48^{\mathrm{d}}$ & $46.4 \pm 1.1^{\mathrm{c}}$ & $53.61 \pm 2.5^{\mathrm{b}}$ & $58.2 \pm 1.3^{\mathrm{a}}$ & $57.32 \pm 2.6^{\mathrm{a}}$ & $55.62 \pm 1.6^{\mathrm{ab}}$ \\
\cline { 2 - 7 } & 20 & $5.86 \pm 1.3^{\mathrm{c}}$ & $10.21 \pm 2.9^{\mathrm{b}}$ & $30.43 \pm 3.6^{\mathrm{ab}}$ & $14.29 \pm 1.4^{\mathrm{a}}$ & $9.73 \pm 1.7^{\mathrm{b}}$ & $11.34 \pm 1.2^{\mathrm{b}}$ \\
\hline
\end{tabular}

Note: In each row different letter means significant differences $(\mathrm{p}<0.05)$

\section{References:-}

1. Adenipekun CO, Fasidi IO (2005) Bioremediation of oil polluted soil by Lentinus subnudus, a Nigerian whiterot fungus. Afr J Biotechnol 4(8):796-798

2. Adejoye OD, Adebayo-Tayo BC, Ogunjobi AA, Olaoye OA, Fadahunsi FI (2006) Effect of carbon, nitrogen and mineral sources on growth of Pleurotus florida, a Nigeria edible mushroom. Afr J Biotechnol 5(14):13551359

3. Bradford MM (1976) A rapid and sensitive method for the quantitation of microgram quantities of protein utilizing the principal of protein dye binding. Analyt Biochem 72:248-254

4. Camarero S, Sarkar S, Ruiz-Duenas FJ, Martı'nez MJ, Martinez AT (1999) Description of a versatile peroxidase involved in natural degradation of lignin that has both Mn peroxidase and lignin-peroxidase substrate binding sites. J Biol Chem 274: 10324-10330

5. Chen DM, Bastias BA, Taylor AFS, Cairney JWG 2003. Identification of laccase-like genes in ectomycorrhizal basidiomycetes and transcriptional regulation by nitrogen in Piloderma byssinum.New. Phytol. 157:547-554

6. Cohen R, Hadar Y, Yarden O (2001) Transcript and activity levels of different Pleurotus ostreatus peroxidases are differentially affected by Mn2?. Environ Microbiol 3(5):312-322

7. Eggert, C., U. Temp, J. F. Dean and K. E. Eriksson (1996). A fungal metabolitemediates degradation of nonphenolic lignin structures and synthetic lignin by laccase. FEBS. Let. 391: 144-148.

8. Espindola LHS, Espindola FS, Freitas GR, Brandeburgo MAM (2007) Biodegradation of Red 40 dye by the Pleurotus sp. Florida.Biosci J 23(3):90-93

9. Farmer VC, Henderson MEK, Russell JD (1960) Aromaticalcohol- oxidase activity in the growth medium of Polystictus versicolor. Biochem J 74:257-262

10. Hatakka A (2001) Biodegradation of lignin. In: Hofrichter M, Steinbu“chel A (eds) Lignin, humic substances and coal, vol 1. Wiley, Weinheim, pp 129-180

11. Han M-J, Chai H-T, Song H-G (2005) Purification and characterization of laccase from the white-rot fungus Trametes versicolour.The J Microbiol 46(6):555-560

12. Heinfling A, Ruiz-Dueñas FJ, Martı'nez MJ, Bergbauer M et al (1998) A study on reducing substrates of manganese-oxidizing peroxidases from Pleurotus eryngii and Bjerkandera adusta. FEBS Lett 428:141-146

13. Jonathan, S.G. (2002). Vegetative growth requirements and antimicrobial of some higher fungi in Nigeria. $\mathrm{Ph}$. D Thesis, University of Ibadan. p. 268

14. Kim SJ, Suzuki N, Uematsu Y, Shoda M (2001) Characterization of aryl alcohol oxidase produced by dyedecolorizing fungus, Geotrichum candidum Dec1. J Biosci Bioeng 91:166-172

15. Kirk TK, Cullen D (1998) Enzymology and molecular genetics of wood degradation by White-rot fungi. In: Young RA, Akthar M (eds) Environmentally friendly technologies for the pulp and paper industry. Wiley, New York, pp 273-307

16. Moore, D. and S. W. Chiu (2001). Fungal products as food. Chap. 10: Bio-Exploitation of Filamentous Fungi (S. B. Pointing \& K. D. Hyde editor). Fungal Diversity Press: Hong Kong. 223-251

17. Martinez AT, Speranza M, Ruiz-Duenas FJ, Ferreira P et al (2005) Biodegradation of lignocellulosic: microbial chemical and enzymatic aspects of the fungal attack of lignin. Int Microbiol 8:195-204 
18. Mikolasch A, Schauer F (2009) Fungal laccases as tools for the synthesis of new hybrid molecules and biomaterials. Appl Microbiol Biotechnol 82:605-624

19. Nwanze PI, Jatto W, Oranusi S, Josiah SJ (2006) Proximate analysis of Lentinus squarrosulus (Mont.) Singer and Psathyrella atroumbonata Pegler. Afr J Biotech 5(4):366-368

20. Ozcan S. and M. Johnston (1999). Function and regulation of yeast hexose transporters. Appl. Microbio Molbiol. 63:554-569.

21. Rothschild, N., C. Novotny, V. Sasek and C.G. Dosoretz (2002). Ligninolytic enzymes of the fungus Irpex lacteus (Polyporus tulipiferae) : isolation and characterization of lignin peroxidase. Enz. Microb. Technol. 31: 627-633

22. Saparrat, M. C. N., M. J. Martinez, H. A. Tournier, M. N. Cabello and A. M.isolated from different substrata. World. J. Microbiol. Biotechnol. 16: 799-803

23. Steffen, K. T., M. Hofrichter and A. Hatakka (2000). Mineralisation of super (14) Clabelledsynthetic lignin and ligninolytic enzyme activities of litter-decomposing basidiomycetousfungi . Appl. Microbio. 54: 819-825

24. Sedmak JJ, Grossberg SE (1977) A rapid, sensitive and versatile assay for protein using coomassie brilliant blue G-250. Anal Biochem 79:544-552

25. Shin K-S, Kim YH, Lim J-S (2005) Purification and characterization of manganese peroxidase of the white-rot fungus Irpex lacteus. J Microbiol 43(6):503-509 